\title{
Whiplash injuries: An update
}

\author{
Robert W Teasell MD FRCPC ${ }^{1}$, Allan P Shapiro PhD ${ }^{2}$
}

\section{RW Teasell, AP Shapiro. Whiplash injuries: An update. Pain Res Manage 1998;3(2):81-90.}

Whiplash injuries remain a significant public health problem throughout the developed industrialized world, with significant socioeconomic consequences. Studies looking at the natural history of whiplash injuries have suffered from problems of selection bias, retrospective reviewing and unclear outcomes. Etiology continues to be controversial, largely because of the misconception that all soft tissue injuries heal within six weeks. Recent studies have implicated the cervical facet joint as a cause of whiplash injury pain. A recent treatment study that successfully eliminated whiplashassociated facet joint pain demonstrated abnormal psychological profiles secondary to pain which normalized with successful pain elimination. The impact of compensation on recovery remains controversial, while the concept that mild traumatic brain injury occurs in the absence of loss of consciousness has been largely refuted. The Quebec Task Force on Whiplash-Associated Disorders recently published a report in which the scientific literature was exhaustively reviewed and has made recommendations regarding the prevention and treatment of whiplash and its associated disorders. The Quebec Task Force highlighted the paucity of good scientific evidence; however, they still provided consensus treatment guidelines, which have not been validated. There continues to be a need for further research.

Key Words: Etiology, Management, Quebec Task Force, Recovery, Whiplash

\section{Mise à jour sur les blessures liées à l'entorse cervicale}

RÉSUMÉ : Les blessures liées à l'entorse cervicale demeurent un problème de santé publique important à travers l'ensemble des pays développés et s'accompagnent de lourdes conséquences socioéconomiques. Les études se penchant sur l'histoire naturelle des blessures liées à l'entorse cervicale contiennent des lacunes critiques liées au biais dans les critères de sélection des articles, à la revue rétrospective des cas et à des résultats imprécis. L'étiologie demeure controversée, principalement parce qu'il est faussement admis que les blessures touchant les tissus mous guérissent en six semaines. Des études récentes ont mis en cause l'articulation facettaire cervicale comme une cause de douleur dans les blessures liées à l'entorse cervicale. Une étude thérapeutique récente où l'on est parvenu à éliminer la douleur associée à l'articulation facettaire cervicale a démontré l'existence de profils psychologiques anormaux secondaires à la douleur qui se normalisaient après son élimination. L'impact des indemnisations sur la guérison reste controversé, tandis que l'on a, en grande partie, réfuté l'hypothèse selon laquelle il survient une blessure cérébrale traumatique mineure sans perte de conscience. Le Groupe de travail québécois sur les troubles associés à l'entorse cervicale a récemment publié un rapport dans lequel la littérature scientifique a été passée en revue de façon exhaustive, et qui contient des recommandations concernant la prévention et le traitement de l'entorse cervicale et des troubles qui y sont associés. Le Groupe de travail québécois a souligné le manque de preuves scientifiques ; cependant, il a émis un consensus sur les lignes directrices de traitement qui n'a pas été validé. En cette matière, il apparaît nécessaire de poursuivre les recherches.
W hiplash injuries remain a significant public health problem throughout the developed industrialized world. In many countries, whiplash injuries have had significant socioeconomic consequences leading to controversial proposals aimed primarily at cost containment. Despite the significant socioeconomic impact of whiplash injuries, high quality scientific research is only beginning to emerge. Adversarial relationships between injured patients and costconscious insurers are often fought out in the legal arena with substantial amounts of money at stake. This medical-legal

\footnotetext{
${ }^{1}$ Department of Physical Medicine and Rehabilitation, ${ }^{2}$ Psychological Services, University of Western Ontario, London Health Sciences Centre, London, Ontario

Correspondence and reprints: Dr Robert W Teasell, London Health Sciences Centre, 339 Windermere Road, London, Ontario N6A 5 A5. 
context encourages extreme viewpoints; often research is used more to support these personal biases than to foster a balanced debate or a therapeutic environment that maximizes recovery. The appropriate therapeutic approach is itself a point of much controversy.

In Quebec, a commissioned study involved a group of clinicians, scientists and epidemiologists who exhaustively reviewed the scientific literature and made public policy recommendations regarding the prevention and treatment of whiplash and its associated disorders (1). The stated reasons for commissioning this study reflected both the magnitude of the problem of whiplash and the perceived paucity of strategies to effectively address it:

The frequency of the clinical entity labelled as whiplash is high, the residual disability of victims appears significant in magnitude, and the costs of care and indemnity are high and rising. There is considerable inconsistency about diagnostic criteria, indications for therapeutic intervention, rehabilitation and the appropriate role of clinicians at all phases of the syndrome. Little is known about primary prevention of the condition, and virtually nothing is known about tertiary prevention of serious disability (1).

The Quebec Task Force Study on Whiplash-Associated Disorders concluded that the scientific evidence regarding whiplash was "sparse and generally of unacceptable quality" and they were forced to rely on "consensus opinion" for treatment recommendations. This article provides an update of recent research looking at the incidence, natural history, etiology and management of whiplash injuries.

The Quebec Task Force (1) adopted the following definition of whiplash:

an acceleration-deceleration mechanism of energy transfer to the neck. It may result from rear-end or side-impact motor vehicle collisions, but can also occur during diving or other mishaps. The impact may result in bony or soft tissue injuries (whiplash injuries), which in turn may lead to a variety of clinical manifestations (Whiplash Associated Disorders).

Typically the injured individual is the occupant of a stationary vehicle that is struck from behind (2-12), although injury frequently occurs following side-on and head-on collisions (4). Injury results when the neck muscular reflexes are unable to compensate for the rapidity of head and torso movement resulting from the acceleration forces generated at the time of impact (13). When the physiological limits of cervical structures are exceeded, anatomical disruption of the soft tissues of the neck (including muscles, ligaments and joints) presumably results in subsequent injury.

The clinical syndrome of whiplash is dominated by head, neck and upper thoracic pain and is often associated with a variety of poorly explained symptoms such as dizziness, tinnitus and blurred vision. The symptom complex is consistent from patient to patient and is frequently complicated by psychological sequelae such as anger, anxiety, depression and concerns over litigation or compensation. Women appear to experience whiplash injuries more often than men (14).

\section{INCIDENCE OF CHRONIC WHIPLASH FOLLOWING MOTOR VEHICLE ACCIDENTS} What is the natural history of the whiplash syndrome? It is difficult to be definitive regarding the incidence of chronic whiplash because there continues to be no prospective studies in anything but selected populations, ie, individuals who attend a specialist's office or seek attention in a hospital emergency room. Two recent retrospective studies that tried to eliminate this selection bias, the Quebec Task Force Cohort Study (1) and the Lithuanian study (15), are of particular interest because they suggest that chronic whiplash syndrome is a questionable entity. Accordingly, they warrant closer scrutiny.

The Quebec Task Force Cohort Study: As part of the Quebec Task Force, Spitzer et al (1) studied a cohort of 2810 subjects who submitted claims of injury in 1987 and who had no previous history of motor vehicle accident (MVA)-related injury. Recovery was defined as no longer receiving insurance payments. Cumulative 'recovery' rates were $22.1 \%$ within one week, $53 \%$ within four weeks, $64 \%$ within 60 days, $87 \%$ by six months and $97 \%$ by one year. The median time to the end of disability compensation was 31 days. However, based on this definition of recovery, it is not clear how many patients actually fully recovered and were asymptomatic, and how many remained both symptomatic and disabled but had their benefits discontinued for lack of a definitive structural (radiological) cause of their symptoms.

The facts that work readiness was the assumed end-point and that few patients received rehabilitation raised concerns that the exceptional recovery rates reported simply reflected an unusually high 'threshold' for allowing continued claims of pain and disability. Indeed, a recent study by Corey et al (16) on outcome in a functional restoration program suggests that discontinuation of insurance benefits is a very questionable indicator of 'recovery'. The authors followed a group of musculoskeletal pain patients who, at three to six months postinjury, were not working and were collecting Workers' Compensation Board benefits. At 18 months postinjury, 80\% of these patients had been deemed 'recovered' because they were no longer receiving wage replacement benefits (17). However, in contrast to this $80 \%$ recovery rate, telephone follow-up at 18 months revealed that only 50\% were either working (24\%) or looking for work (26\%). Although we cannot directly extrapolate these findings to the Quebec Task Force cohort, it is clear that defining recovery as discontinuance of insurance benefits significantly overestimates return to work and resolution of symptomatology in soft tissue injuries.

The Lithuanian Study: Schrader and colleagues (15) used police accident records from a city in Lithuania to identify 202 individuals whose cars were rear-ended in automobile collisions one to three years (mean 21.7 months) earlier. They compared these subjects with a nonaccident control group selected randomly from the population register and 
found no statistically significant differences between groups in the incidence of neck/back pain, headache or memory/concentration difficulties. They concluded that "the late whiplash syndrome has little validity" and argued that reports of chronic whiplash in other countries are likely due to the existence of a medical-legal context that compensates whiplash injury - in Lithuania few drivers are covered by auto insurance. However, closer analysis reveals significant methodological shortcomings that render the authors' conclusions regarding whiplash dubious at best.

The sex ratio in the Lithuanian accident group was four males to one female, whereas most studies on chronic whiplash report a higher ratio of females to males, ostensibly because females have smaller neck musculature, which renders them less able to resist the damaging acceleration forces generated at the time of impact (18). A review of the scientific literature on sex variation and pain concluded that women are more likely than men to experience a variety of recurrent pains and report more severe levels of pain, more frequent pains and pain of longer duration (19). Likewise, compared with men, women report higher rates of disability for cervical pain (20) and headache (21). Accordingly, the sex bias in the Lithuanian study likely resulted in a significantly lower incidence of chronic pain and disability.

Only 31 of the 202 accident subjects in the Lithuanian study actually reported any acute injury, and of these, only nine reported that their pain lasted a week or more. A prospective study from Switzerland enrolled acute whiplash injury victims an average of one week after their injury (22). Subjects had pain on entering the study. The authors found that $24 \%$ of subjects continued to report symptoms at one year follow-up and $18 \%$ at two years (22). Based on this research we expect that of the nine Lithuanian accident victims whose pain lasted more than a week, $18 \%$ to $24 \%$, or approximately two subjects, would continue to report symptoms long term. Indeed, the Lithuanian study reported that three more subjects in the accident group reported chronic neck pain compared with the controls, a difference that, given the small sample, did not reach statistical significance.

Although the conclusion by Schrader and colleagues (15) that the whiplash syndrome "has little validity" was not supported by their data, they hypothesized that the high incidence of chronic neck pain after automobile accidents in countries with a medical-legal context can be attributed to pre-existing neck pain that is erroneously attributed to the automobile collision. Indeed, these same researchers (23) conducted a cross-sectional survey to determine the frequency and duration of neck pain in Norwegian adults. Among the $77 \%$ of the 9918 persons who responded, $13.8 \%$ reported chronic (longer than six months) neck pain with women more affected then men (17\% versus $10 \%)$. The authors concluded that the "similarity between prevalence of chronic neck pain in the general population and that after trauma with whiplash mechanism, makes a significant pathogenic role for the latter unlikely". Such a conclusion is, however, unwarranted given, first, the high nonresponse rate
TABLE 1

Review of cohort studies of recovery of whiplash patients

\begin{tabular}{|c|c|c|c|c|}
\hline \multirow{2}{*}{$\begin{array}{l}\text { Time } \\
\text { since } \\
\text { MVA }\end{array}$} & \multicolumn{4}{|c|}{ Study (reference) } \\
\hline & QTF (1)* & $\begin{array}{l}\text { Gargan et al } \\
(25)^{\dagger}\end{array}$ & $\begin{array}{l}\text { Radanov et } \\
\text { al }(22)^{\dagger}\end{array}$ & $\begin{array}{l}\text { Hildingsson } \\
\text { et al }(26)^{\dagger}\end{array}$ \\
\hline 3 months & $70 \%$ & $30 \%$ & $56 \%$ & - \\
\hline 6 months & $87 \%$ & - & $69 \%$ & - \\
\hline 1 year & $97 \%$ & $52 \%$ & $76 \%$ & - \\
\hline 2 years & - & $38 \%$ & $82 \%\left(96 \%^{\ddagger}\right)$ & $42 \%\left(57 \%^{\ddagger}\right)$ \\
\hline
\end{tabular}

\begin{tabular}{|c|c|}
\hline & Number (estimates) \\
\hline Rear-end collision & 1000 \\
\hline \multicolumn{2}{|l|}{ Pain after collision } \\
\hline Initially & $200-250$ \\
\hline One week & $60-75$ \\
\hline 3 months & $26-34$ \\
\hline 6 months & $19-24$ \\
\hline 1 year & $15-19$ \\
\hline 2 years & $11-14$ \\
\hline
\end{tabular}

(23\%), which could have resulted in an overestimation of neck pain prevalence, and, second, the lack of any definitive data on actual incidence of chronic whiplash after MVAs. Indeed, their more recent Lithuanian study (15) comprises a more appropriate methodology (if there were adequate statistical power and nonbiased sampling) to address the issue of whether an MVA is a significant risk factor for the development of chronic neck pain.

Prospective studies looking at selected populations: The study by Radanov et al (22) is widely regarded as the best current study of whiplash. These authors looked at whiplash patients recruited from family doctors in Switzerland almost immediately (on average one week) after injury. Subjects were insured under a typical no-fault insurance plan with no compensation for noneconomic loss, ie, pain and suffering. One hundred and sixty-four consecutive patients were referred of whom 27 did not meet study criteria and 20 dropped out at the six-month follow-up. A total of 117 subjects (74 women, 43 men) completed the study at one year. Within 10 days of injury, patients underwent a thorough physical and psychosocial assessment. Recovery at three-, six- and 12-month follow-up was 56\%, 69\% and 76\%, respectively.

Nygren (24) found chronic pain and long term disability in $10 \%$ of patients who initially complained of neck pain after 
rear-end collisions. They were felt to have suffered a permanent medical disability because of persistent symptoms five years after the MVA. Other prospective studies looking at selected populations, either attending an emergency room or a specialty clinic, have demonstrated failure to recover in $62 \%$ (25) and 58\% (26) of whiplash patients, respectively. This finding reflects the results of many other studies on whiplash. Unfortunately, there are significant limitations to extrapolating these studies to the whiplash population as a whole. As is evident from Table 1, the majority of individuals who recover do so within the first three to six months, and this finding will significantly influence studies that select patients on the basis of entering a specialized clinic. The Radanov et al (22) study comes the closest to avoiding the selection bias that besets other prospective studies.

A definitive study has yet to be done. Such a study needs to follow a truly representative cohort of accident victims prospectively with objective outcome measures of residual physical symptomatology and function. The same methodology could be applied in a country without any recourse to insurance benefits to control for the impact of a medical-legal context. Based upon currently available data, Table 2 provides an estimate of the incidence and expected rate of recovery of whiplash injuries.

\section{PATHOPHYSIOLOGY}

The pathological lesions accounting for chronically symptomatic whiplash injuries are by no means certain. Injuries to the muscles of the neck, including stretching, tearing and hemorrhaging of the longus colli, longus capitis, scalene and sternocleidomastoid muscles, have been postulated but not proven - to be the primary cause of pain (27).

\section{Normal healing time}

A critical element of the debate regarding pathophysiology revolves around the normal anticipated time for musculoligamentous healing to occur. The Quebec Task Force noted,

Apart from anatomic studies, much of the scientific understanding of soft tissue injury and healing is derived from animal models, and there is little information on the normal recuperation period. In the animal model of soft tissue healing, there is a brief period (less than 72 hours) of acute inflammation and reaction, followed by a period of repair and regeneration (approximately 72 hours to up to 6 weeks), and finally by a period of remodelling and rematuration that can last up to 1 year (1).

The applicability of these animal studies to humans becomes suspect when one considers common musculoskeletal sports injuries involving the rotator cuff or internal derangement of the knee. Although these injuries usually heal rapidly, some injuries persist and in the case of many professional athletes are career-ending, despite access to first rate medical care. Despite this evidence that not all soft tissue injuries heal, the persistence of pain in a certain percentage of patients with whiplash injuries has remained a source of controversy. Be- low we review the most recent research that suggests that physical pathology accounts for persistent whiplash pain.

\section{Evidence that physical pathology accounts for non- resolution of symptoms}

Cervical facet joint and discogenic injuries: It has long been argued that whiplash injuries have a physiological basis given the consistency of the clinical picture in many countries and across varying cultures (2). Two Australian studies $(28,29)$ have recently provided evidence implicating the cervical facet joint as a potential source of chronic pain following whiplash trauma. In these blinded studies $(28,29), 50$ and 68 consecutively referred patients, respectively, with chronic neck pain after whiplash injury were assessed by means of controlled diagnostic blocks of cervical zygapophyseal joints. Each joint was separately injected with short-acting (lignocaine) or long-acting (bupivacaine) local anesthetics. Fiftyfour per cent (27 of 50) and 60\% (41 of 68) of these chronic whiplash patients experienced pain relief from injections concordant with the expected duration of the anesthetic. In the latter study (29), control saline blocks were also used.

Recently, the same Australian investigators (30), using radiofrequency neurotomy of the dorsal cervical rami, achieved virtually complete relief of chronic whiplash pain in patients with a median pain duration of 34 months. In this randomized, double-blind clinical trial, seven of 12 patients receiving the active treatment obtained pain relief in excess of six months. Only one of 12 patients in the sham surgical placebo control group was pain-free. In a subsequent paper summarizing their work to date, these authors (31) reported that a second neurotomy was successful in re-eliminating pain in eight of nine patients in whom pain eventually returned after the first successful radiofrequency neurotomy. These demonstrations of facet joint involvement in chronic whiplash pain are consistent with previous studies demonstrating facet joint injuries in experimental animals $(10,32)$ and cadavers $(33,34)$ subjected to experimental acceleration deceleration injury. Their results also lend further credence to postmortem studies of MVA victims, which have shown that zygapophyseal joint injuries are common (35).

The same Australian researchers (36) also convincingly demonstrated that the psychological distress often evident in chronic whiplash patients is a consequence of the pain and appears to have no etiological significance. As part of their protocol for treating zygapophysial joint pain by using radiofrequency neurotomy, they administered the Symptom Checklist 90 (SCL-90) (National Computer Systems, Inc, Minnesota) both before and after treatment. The typical SCL-90 profile pretreatment showed clinically significant elevations of the Somatization, Depression and ObsessiveCompulsive scales. Successful relief of pain following neurotomy resulted in significant reduction of elevated scale scores to levels consistent with nonclinical ('normal') populations. When the pain eventually returned, the SCL-90 scales again became elevated. Moreover, after a second neurotomy successfully re-eliminated the pain, the elevated SCL-90 scale scores once again decreased to normal levels (36). 
Taylor and Twomey (37) provided suggestive evidence of physical pathology when they compared autopsies of the cervical spine of 16 subjects who died of major trauma with 16 aged-matched subjects who died of natural causes. Lesions attributable to antemortem trauma were found in 15 of the 16 subjects who died of major trauma. All 15 demonstrated linear clefts (continuous split between the tissue planes of the cartilage and the annulus) within the cartilage plate, in one or more cervical discs (average of three discs affected). The lesions included six traumatic disc ruptures with posterior herniation, 10 lesions involving annular bruising (blood within the outer annulus) and 21 examples of soft tissue damage to the synovial joints. These latter facet joint injuries consisted mostly of hemarthroses, presumably from small capsular or synovial tears. These were most frequently found in spines where there was a probable flexion injury. Occult damage to bone or cartilage of facet joints was uncommon when compared with disc damage.

These findings are in marked contrast with those from control subjects where only two small defects in the cartilage plates near the vertebral body were found. The same authors provided evidence that deep rim lesions of the disc annulus, as evidenced in the post-trauma victims, often did not heal and were associated with early disc degeneration at that level. The forces experienced at the cervical spine in individuals killed by trauma are likely of greater magnitude than those in simple whiplash trauma, thus limiting the applicability of this study. However, these findings illustrate that MVAassociated lesions of the cervical spine, of sufficient magnitude and not observable with standard radiographic techniques, occur with similar (albeit more severe) trauma (37).

Physical factors predict chronic symptomatology: Further evidence supporting a physical basis for chronic whiplash pain comes from a recent prospective study that suggested physical but not psychological factors predict nonresolution of whiplash pain. In a prospective study of whiplash patients recruited through family physicians in Switzerland, subjects underwent neurological evaluation and completed a semistructured interview, various self-report questionnaires (including ratings of mood and cognitive function) and personality inventories within 10 days (mean 7.4 days) of injury (22).

At one year follow-up these same researchers (38) reported that $24 \%$ of the study subjects were still symptomatic. Baseline factors differentiating symptomatic from asymptomatic subjects were rotated or inclined head position at impact; unpreparedness at time of impact; the car being stationary when hit; and initial intensity of neck pain and headache. They reported that a rotated or inclined head position and unpreparedness at time of impact were predictive of more severe acute (at one week) injury as evidenced by higher frequency of multiple symptoms and radicular involvement, more signs of cervical strain and more severe headaches. Psychological and personality traits were still not predictive of failure of symptoms to resolve at one year postinjury. The authors concluded that "accident mechanisms and initial findings suggestive of more severe injury were significantly related to long-term persistence of symptoms after a whiplash injury" $(38,39)$.

Taken together, all of these studies strongly point to a pathophysiological basis for chronic pain in most, if not all, patients who have incurred a whiplash injury. However, in the Australian studies, a significant proportion did not exhibit an analgesic response to the diagnostic blocks, raising questions regarding different etiologies of whiplash injury and the accuracy of the technique in determining causation. As well, it would be helpful to know what percentage of patients with chronic neck pain but no history of cervical flexion-extension injury would respond similarly to diagnostic analgesic blocks and subsequent neurotomy, that is, how specific are these findings to 'chronic whiplash' versus chronic neck pain of unspecified origin? While these studies convincingly demonstrate that psychological distress is secondary to pain, it is still possible that in a subset of patients, initial pain interacts with premorbid personality to produce significant distress which then exacerbates pain in a cyclical fashion.

\section{IMPACT OF LITIGATION AND COMPENSATION ON WHIPLASH} The argument that litigation and compensation inhibit whiplash recovery

Historically, the absence of clear pathophysiology and the fact that whiplash is frequently associated with litigation, have contributed to the belief that whiplash symptoms fail to resolve in some patients because of nonphysical factors. Evidence that whiplash is uncommon (albeit in methodologically poor studies) in countries where compensation is not available $(15,40)$ and that the amount of compensation available can influence the incidence of claims (41), has led to the concept of 'compensation neurosis'. Awerbuch (41) reviewed studies comparing the incidence of whiplash claims in various countries and jurisdictions that differ with respect to laws that compensate chronic pain secondary to MVAs. On the basis of this review he concluded that "comparative studies suggested that, 'whiplash' is an illness reinforced by legal and social sanction". Similarly, the Quebec Task Force Study on Whiplash-Associated Disorders (1) noted that the percentage of motor vehicle claims paid out for whiplash under the Quebec no-fault system appeared to be only a fraction of that paid out by two other Canadian provinces (Saskatchewan and British Columbia) who had a tort system. The authors argued that a tort claim system discourages recovery and encourages disability. Turk (42), in recently discussing chronic pain in general, noted that "despite study limitations, it appears that compensation factors may contribute to delayed recovery and may reinforce the sick role". Insurance industry and media reports of fraudulent whiplash claims are common and must also be considered.

\section{The argument that litigation and compensation do not inhibit whiplash recovery}

In contrast, the consensus of most authorities involved in the treatment of chronic pain including whiplash is that malingering is rare and likely accounts for less than $10 \%$ of those 
seen in tertiary pain clinics. Shapiro and Roth (43), in their review of the effect of litigation on whiplash, concluded that there was no evidence that settlement of litigation leads to resolution of whiplash symptomatology. Although they found some reports of symptomatic recovery following settlement of claims, these retrospective studies were based on nonrandom, unrepresentative and poorly defined patient samples, did not include control groups and failed to use standardized techniques of measurement or appropriate statistical analyses. Moreover, in the majority of these reports, a significant proportion of patients recovered before settlement of litigation, and resolution of court claims was not associated with recovery for the majority. Likewise, Dworkin (44) argued that studies that examined the role of compensation neglected to consider that compensation may be a consequence of chronic pain. It was suggested that compensation may be related to greater pain, disability, psychological disturbance and poorer response to treatment. Such factors have been interpreted as a consequence of compensation rather than causative.

\section{Why such divergent opinions?}

Potential subsets of patients: In order to make sense of these apparently divergent observations and the associated contentious and often highly emotional debate, it is necessary to consider the likelihood that compensation/tort systems have different effects on reports of pain and disability depending upon the particular nature of the claimant population. It is likely that there are claimants who really have no injury whatsoever, have a pre-existing pain problem unaffected by the accident that they fraudulently attribute to the MVA or have relatively minor symptoms for which they are claiming compensation. These claimant populations may become nonclaimants in jurisdictions where the threshold for accepting a claim is much higher or where there is no medico-legal context whatsoever for compensating whiplash. As well, the vast majority of such claimants are likely weeded out of the system or readily accept minor settlements before they are seen in tertiary treatment settings and/or are subjected to the intense scrutiny typical of a prolonged, extremely adversarial and highly costly litigation process.

Selection biases: In contrast, the population generally seen in specialty clinics (from whom most research and commentary arises) comprises patients reporting the most severe pain and disability who readily accept and often demand referrals to tertiary-based pain and rehabilitation specialists. This population likely represents a very small (less than 10\%) proportion of those initially injured in MVAs. For this population, settlement of litigation may even be associated with improvement but not resolution of symptoms. Specifically, in our own research we found that compared with chronic whiplash patients who had completed litigation, active litigants reported higher ratings of pain severity, pain in more body sites, greater use of pain medication and more functional impairment (45). The group did not differ with respect to work status. This was the case even after statistically con- trolling for time since injury and retrospective report of severity of initial symptomatology.

Unique impact of litigation and compensation: In interpreting the above findings, it was noted that chronic whiplash patients may be unique in the degree to which their pain and disability is viewed with scepticism not only in the context of the medical-legal process, but also by both professionals and the general public. At the same time, they look to the litigation system because they fear that pain will render them unable to work competitively and/or their pain and disability will increase over time leaving them with no recourse should they find themselves unable to work in the future. Under these circumstances, these patients may have a greater need to communicate the degree of their pain and ensure that the extent of their pain and disability is not underestimated. In this regard, pain symptoms and associated disability vary and patients have good days and bad days. Although patients involved in litigation may emphasize the latter, this is not unique to medical-legal contexts. Indeed cancer patients' ratings of the impact of pain on day-to-day functioning is most closely associated with their ratings of 'worst pain' and unrelated to their 'average' and 'least' pain ratings (46). As well, as the case invariably drags on, financial compensation for lost wages and treatment is often delayed or inadequate, creating financial stresses and anxiety. Financial worries may be compounded by mounting legal bills, which ultimately must be paid regardless of the outcome of the lawsuit. The litigation process is itself extremely adversarial, which creates even more stress. The resulting anxiety often overwhelms the patient and may serve to increase pain.

\section{Impact of whiplash and compensation: A system approach}

Shapiro and Roth (43) have proposed a systems model in which the impact of litigation/compensation on return to work is a function of patients' expectation of their ability to attain their pre-injury work status successfully despite residual pain. This self-efficacy expectation is, in turn, influenced by a host of variables, including level of pain and disability, psychosocial and ergonomic workplace factors, family and treatment variables, personality, socioeconomic conditions and the stress associated with the adversarial litigation/compensation system. Despite evidence that supports this biopsychosocial conceptualization of the impact of compensation/litigation on chronic whiplash, there remains a strong bias to adopt simplistic notions such as malingering, secondary gain, dislike of work and monetary gain/greed. Fishbain (47) has cogently critiqued the concept of secondary gain in chronic pain disorders. The secondary losses associated with chronic pain - including loss of finances, marital breakdown, loss of work status, anxiety and depression - generally far outweigh any secondary gain available through third-party payers.

In summary, the impact of compensation on whiplash symptoms and disability comes largely from research plagued by methodological difficulties; however, it is difficult to dismiss the potential impact of this factor on symptom 
presentation and severity. At the same time, it is critical to consider how a medico-legal context can differentially affect various claimant populations. A system that vigorously denies every claim may well result in fewer fraudulent and exaggerated claims. However, it may also inadvertently accentuate pain, disability and suffering in legitimate claimants who are most severely affected by their injury (43).

\section{MILD TRAUMATIC BRAIN INJURY ASSOCIATED WITH WHIPLASH}

Memory and concentration difficulties are frequently reported in patients with chronic whiplash symptoms. However, the etiology of these particular cognitive complaints has become controversial with the attribution of these symptoms to minor brain injury purportedly suffered at the time of impact.

\section{The hypothesis}

In recent years, a number of researchers have argued that cognitive difficulties reported by patients with whiplash are the result of a mild traumatic brain injury sustained as a consequence of violent hyperflexion and hyperextension of the neck (48-52). This injury has been postulated to occur on vehicular impact because the skull accelerates faster than the brain and subsequently impacts with the brain as it rotates backward or accelerates forward. Mild traumatic brain injury has been postulated to occur despite that at the time of the accident patients with whiplash rarely experience loss of consciousness or post-traumatic amnesia, both considered by some authorities to be important diagnostic criteria for mild traumatic brain injury (53-55). Although some laboratory studies using nonhuman primates indicate that brain damage can occur in simulated hyperextension-flexion or acceleration injuries without loss of consciousness (56-59), the anatomy of nonhuman primates is markedly different from that of humans. This renders animal data suggestive but emphasizes the need for confirmatory human research (60).

\section{Lack of evidence for mild traumatic brain injury}

A review of human research finds little or no evidence for enduring brain injury after whiplash $(60,61)$. There is no conclusive evidence for neuropathological abnormalities after whiplash. A number of studies have reported electroencephalogram (EEG) abnormalities suggestive of brain injury in patients with whiplash; however, the reported incidence of these abnormalities ranges from $4 \%$ to $46 \%$ (62-64). Although all of the EEG studies have methodological problems, the study reporting the highest incidence of EEG abnormalities (46\%) is particularly flawed (62).

Neuropsychological assessment is thought to be more sensitive for detecting mild brain injury, and a number of studies report poorer performance on neuropsychological measures of concentration and memory in groups of chronic whiplash patients one or more years after injury (49-52). Patients in these studies usually are recruited from specialty clinics and typically represent a select sample with longstanding complaints of disabling pain, emotional distress and
TABLE 3

Specific interventions for whiplash-associated disorder

\begin{tabular}{|c|c|}
\hline Intervention & Study to establish benefit \\
\hline \multicolumn{2}{|l|}{ Immobilization } \\
\hline Soft collars & $\begin{array}{l}\text { Only studied in control groups. } \\
\text { May delay recovery by pro- } \\
\text { moting inactivity (studies) }\end{array}$ \\
\hline Rest & $\begin{array}{l}\text { No studies. Prolonged rest likely } \\
\text { detrimental to recovery }\end{array}$ \\
\hline Cervical pillows & No studies \\
\hline \multicolumn{2}{|l|}{ Activation } \\
\hline Manipulation & $\begin{array}{l}\text { No acceptable studies establishing } \\
\text { short term or long term effec- } \\
\text { tiveness }\end{array}$ \\
\hline Mobilization & $\begin{array}{l}\text { No studies. Likely beneficial over } \\
\text { short term. Long term benefit } \\
\text { not established }\end{array}$ \\
\hline Exercise & $\begin{array}{l}\text { Not independently studied. } \\
\text { As part of a "multimodal inter- } \\
\text { vention" may be beneficial }\end{array}$ \\
\hline Traction & $\begin{array}{l}\text { Not independently studied. } \\
\text { No benefit demonstrated }\end{array}$ \\
\hline Postural advice & Not independently studied \\
\hline Spray and stretch & No studies \\
\hline \multicolumn{2}{|c|}{ Passive modalities and electrotherapies } \\
\hline TENS & No studies \\
\hline $\begin{array}{l}\text { Pulsed electromagnetic } \\
\text { treatment }\end{array}$ & No benefit (study) \\
\hline Electrical stimulation & No studies \\
\hline Ultrasound & No studies \\
\hline Laser, heat, ice, massage & No studies \\
\hline Surgery & No studies \\
\hline \multicolumn{2}{|l|}{ Injections } \\
\hline Nerve block & No studies \\
\hline Epidural injections & No studies \\
\hline Facet joint injection & No benefit (study) \\
\hline $\mathrm{S} / \mathrm{C}$ sterile water injections & $\begin{array}{l}\text { Some benefit compared with normal } \\
\text { saline in unblinded study }\end{array}$ \\
\hline $\begin{array}{r}\text { Pharmacological } \\
\text { interventions }\end{array}$ & No studies \\
\hline Psychological treatment & No studies \\
\hline \multicolumn{2}{|l|}{ Other interventions } \\
\hline Prescribed function & Improved outcome in one study \\
\hline Acupuncture & No studies \\
\hline Magnetic necklace & No benefit (study) \\
\hline
\end{tabular}

S/C Subcutaneous; TENS Transcutaneous electrical nerve stimulation

cognitive difficulties. These studies have failed to control for the documented effects of pain, medications, depression and anxiety/arousal on cognitive functioning $(60,61)$.

The effects of emotions and medication on cognitive functioning are well documented. Studies on the deleterious effect of pain on attentional processes and task performance are more recent (65). 
It is of note that the literature on mild traumatic brain injury suggests that difficulties in cognitive functioning, as assessed by neuropsychological testing, normalize by three months after injury (66-69). Given this literature on recovery of function in mild traumatic brain injury and research documenting the deleterious effect of pain and emotional distress on cognitive functioning $(65,70-74)$, one need not postulate a traumatic brain injury to account for persisting cognitive problems in samples of chronic whiplash patients (60). In fact, the only prospective study to follow an unselected sample of patients with whiplash found no evidence of cognitive deficits six months after injury (75). Two prospective studies assessing neuropsychological functioning within a week of injury failed to use adequate control groups $(75,76)$. Accordingly, a definitive prospective study of acute cognitive deficits related to mild traumatic brain injury that adequately controls for pain and emotional functioning has yet to be performed.

In conclusion, cognitive (attentional or memory) difficulties are common following whiplash injuries. However, there is little evidence that these deficits are related to a traumatic brain injury, and alternative explanations for symptoms remain more plausible.

\section{MANAGEMENT OF WHIPLASH INJURIES Quebec Task Force Review of Whiplash-Associated Disorders}

Review of interventions: The Quebec Task Force compiled a 'best evidence' synthesis of treatment interventions (1). This was an important study in that both Quebec, and to some extent Ontario, have adopted it as a guideline to treat whiplash patients. For almost every treatment the Quebec Task Force found either no studies or a lack of independent studies, ie, the specific intervention was only included in multiintervention studies or in conditions other than whiplash. Only facet joint injections, pulsed electromagnetic treatment and magnetic necklace were found to be of no benefit in acceptable clinical trials, and even these conclusions were based on only one study for each treatment. The Quebec Task Force's conclusions for each treatment are outlined in Table 3 ; the most common conclusion was "no studies". Therefore, for the vast majority of treatments reviewed, one cannot definitively conclude whether they are effective or ineffective, just that they have not been studied in isolation. However, because many of these treatments were incorporated as part of multi-intervention procedures that were of limited benefit, it would be surprising if they proved to be efficacious in isolation. That is, for most treatments of whiplash, proof of efficacy does not exist and the trend of evidence does not support their use.

Consensus treatment guidelines: Despite the absence of scientifically rigorous information, the Quebec Task Force proposed a set of treatment recommendations "based on the best evidence available, or where evidence was lacking, on the combined experience and judgement emerging from extended in-depth discussions of the Task Force members". This represents a remarkable paradox whereby data are re- jected based on nonrigorous scientific criteria while consensus guidelines are adopted and promoted in the same nonrigorous manner. The danger of such consensus guidelines, provided in the face of little scientific evidence, is that they give the false impression of being built on a foundation of scientific truth or facts. Even more worrisome was the fact that the government no-fault insurance carrier, hardly a disinterested party, funded this consensus development. Consensus was reached using a panel which, with two exceptions, had a relatively sparse or nonexistent publication record in the area of whiplash. Moreover, the guidelines did not address the issue of chronic whiplash. That is, treatment recommendations were for the first 12 weeks postinjury. Accordingly, the apparent wholesale adoption of these guidelines by the insurance community is questionable at best and could be construed as particularly self-serving.

\section{Multidisciplinary treatment}

Provinciali et al (77) recently studied the efficacy of a multidisciplinary rehabilitation approach to whiplash. Sixty patients with whiplash injuries were recruited within two months of injury (average 30 days). Patients were randomly assigned to one of two treatment conditions: a multidisciplinary treatment consisting of postural training, manual therapies and psychological intervention (primarily 10 sessions of relaxation training); or a control group using several physical modalities only. Patients receiving the multidisciplinary treatment regimen fared significantly better in terms of pain reduction, self-assessment of recovery and return to work at six months when compared with the physical treatment group. Neck range of motion was not statistically different between the two groups. The authors argued that multiple factors may influence the late whiplash syndrome and, in particular, speculated that psychological support (primarily relaxation training) may have reduced the emotional influence on muscle tone and increased pain tolerance.

\section{Conclusions on treatment}

In summary, the Quebec Task Force on Whiplash-Associated Disorders has appropriately identified the paucity of evidence-based research for whiplash treatments. A single randomized controlled trial has suggested that a multidisciplinary treatment approach early in the course of whiplash injury may be beneficial. As discussed earlier, a wellcontrolled trial of radiofrequency coagulation denervation of facet joints that were identified as being the source of pain was highly promising (30) and this may yet prove an effective treatment in a subset of chronically symptomatic patients. However, such an approach is technically difficult, and may need to be repeated at six months or yearly intervals.

\section{SUMMARY}

Whiplash injuries are a significant public health problem throughout the industrialized world, with significant socioeconomic consequences. The natural history of whiplash injuries has yet to be definitely studied. Studies suffer from unclear outcome measures, are retrospective in nature or suf- 
fer from large selection biases. By combining these studies one can develop a natural history for whiplash injuries in the aggregate. Etiology of chronic symptoms remains controversial; however, the argument that all soft tissue injuries heal within six weeks seems to be based on limited evidence. In contrast, carefully controlled studies have strongly implicated the facet joint as a significant source of ongoing whiplash pain. Psychological distress appears to be a consequence of whiplash pain, with a recent treatment study demonstrating that abnormal psychological profiles are secondary to pain and normalize with successful pain elimination. How-

\section{REFERENCES}

1. Spitzer WO, Skovron ML, Salmi LR, et al. Scientific monograph of the Quebec Task Force on Whiplash-Associated Disorders: redefining "whiplash" and its management. Spine 1995;20(Suppl):1S-73S.

2. Bogduk N. The anatomy and pathophysiology of whiplash. Clin Biomech 1986;1:92-101.

3. Commack KV. Whiplash injuries to the neck. Am J Surg 1957;93:663-6.

4. Deans GT. Incidence and duration of neck pain among patients injured in car accidents. Br Med J 1986;292:94-5.

5. Frankel VH. Pathomechanics of whiplash injuries to the neck. In: Morley TP, ed. Current Controversies in Neurosurgery. Philadelphia: WB Saunders 1976:39-50.

6. Hohl M. Soft tissue injuries of the neck in automobile accidents: Factors influencing prognosis. J Bone Joint Surg 1974;56A:1675-82.

7. LaRocca H. Acceleration injuries of the neck. Clin Neurosurg 1978;25:205-17.

8. Macnab I. Acceleration extension injuries of the cervical spine. J Bone Joint Surg Am 1964;46:1797-9.

9. Macnab I. Acceleration extension injuries of the cervical spine. In: AAOS Symposium of the Spine. St Louis: CV Mosby, 1969:10-7.

10. Macnab I. The "whiplash syndrome". Orthop Clin North Am 1971;2:389-403.

11. Macnab I. The whiplash syndrome. Clin Neurosurg 1973;20:232-41.

12. Macnab I. Acceleration extension injuries of the cervical spine. In: Rothman RH, Simeone FA, eds. The Spine, 2nd edn. Philadelphia: WB Saunders, 1982:647-60.

13. Hohl M. Soft tissue neck injuries. In: The Cervical Spine Research Society Editorial Committee, eds. The Cervical Spine, 2nd edn. Philadelphia: JB Lippincott Company, 1989:436-41.

14. Balla JI. The late whiplash syndrome. Aust NZ J Surg 1980;50:610-4

15. Schrader H, Obelieniene D, Bovim G, et al. Natural evolution of late whiplash syndrome outside the medicolegal context. Lancet 1996;347:1207-11.

16. Corey DT, Koepfler LE, Etlin D, Day IH. A limited functional restoration program for injured workers: a randomized trial. J Occup Rehab 1996;6:239-9.

17. Mitchell RI, Carmen GM. The functional restoration approach to the treatment of chronic pain in patients with soft tissue and back injuries. Spine 1994;19:633-42.

18. Teasell RW, Shapiro AP. Flexion-extension injuries and chronic pain. In: Merskey H, Vaeroy H, eds. Pain Research and Clinical Management Progress on Fibromyalgia and Myofascial Pain, vol 6. Amsterdam: Elsevier, 1996:253-66.

19. Unruh AM. Gender variations in clinical pain experience. Pain 1996;65:123-67.

20. Havold T, Johnsen R. Headache and neck or shoulder pain - frequent and disabling complaints in the general population. Scand J Prim Health Care 1993;11:219-24.

21. Taylor H, Curran NM. The Nuprin Pain Report. New York: Louis Harris and Associates Inc, 1985.

22. Radanov BP, Sturzenegger M, DeStefano G, Schnidrig A. ever, this is not to say that psychological factors have no impact on symptom presentation.

The Quebec Task Force on Whiplash-Associated Disorders highlighted the paucity of good scientific evidence while providing consensus guidelines despite a lack of acceptable scientific data. A single randomized controlled study has suggested that a multidisciplinary treatment approach is more effective than a variety of physical modalities. Facet joint denervation via percutaneous neurotomy represents a promising new treatment. There remains an obvious need for further research.

Relationship between early somatic, radiological, cognitive and psychosocial findings and outcome during a one-year follow-up in 117 patients suffering from common whiplash. Br J Rheumatol 1994;33:442-8.

23. Bovim G, Schrader H, Sand T. Neck pain in the general population. Spine 1994;19:1307-9.

24. Nygren A. A study of a five-year material from an insurance company. Acta Laryngol Suppl 1984;395:1-64.

25. Gargan MF, Bannister GC. The rate of recovery following whiplash injury. Eur Spine J 1994;3:162-4.

26. Hildingsson $\mathrm{C}$, Toolanen $\mathrm{G}$. Outcome after soft tissue injury of the cervical spine. Acta Orthop Scand 1990;614:357-9.

27. Lieberman JS. Cervical soft tissue injuries and cervical disc disease. In: Leek JC, Gershwin ME, Fowler WM, eds. Principles of Physical Medicine and Rehabilitation in the Musculoskeletal Diseases. New York: Grune \& Stratton, 1986:263-86.

28. Barnsley L, Lord SM, Wallis BJ, Bogduk N. The prevalence of chronic cervical zygapophysial joint pain after whiplash. Spine 1995;20:20-5.

29. Lord SM, Barnsley L, Wallis BJ, Bogduk N. Chronic cervical zygapophysial joint pain after whiplash. A placebo-controlled prevalence study. Spine 1996;21:1737-45.

30. Lord SM, Barnsley L, Wallis BJ, McDonald GJ, Bogduk N. Percutaneous radio-frequency neurotomy for chronic cervical zygapophyseal-joint pain. N Engl J Med 1996;335:1721-6.

31. McDonald G, Lord S, Bogduk N. Long-term audit of radiofrequency neurotomy for cervical zygapophysial joint pain. 1997 Spine Society of Australia Scientific Meeting. Gold Coast, Queensland, Australia, May 10, 1997.

32. Wickstrom JK, Rodriguez RP, Martinez JL. Experimental production of acceleration injuries of the head and neck. Washington: Highway Safety Research Institute 181, 1967.

33. Abel MS. Moderately severe whiplash injuries of the cervical spine and roentgenologic diagnosis. Clin Orthop 1958;12:189-208.

34. Clemens HJ, Burow K. Experimental investigation on injury mechanisms of cervical spine at frontal and rear-frontal vehicle impacts. In: Proceedings of the Sixteenth STAPP Car Crash Conference. Warrendale: Society of Automotive Engineers, 1972:76-104.

35. Jonsson H Jr, Bring G, Ranschning W, Sahlstedt B. Hidden cervical spine injuries in traffic accident victims with skull fractures. J Spinal Disord 1991;4:251-63.

36. Wallis BJ, Lord SM, Bogduk N. Resolution of psychological distress of whiplash patients following treatment by radiofrequency neurotomy: a randomized, double-blind, placebo-controlled trial. Pain 1997;31:15-22.

37. Taylor JR, Twomey LT. Acute injuries to cervical joints. Spine 1993;18:1113-22.

38. Sturzenegger M, Radanov BP, DiStefano G. The effect of accident mechanisms and initial findings on the long-term course of whiplash injury. J Neurol 1995;242:443-9.

39. Sturzenegger M, DiStefano G, Radanov BP, Schnidrig A. Presenting 
symptoms and signs after whiplash injury. The influence of accident mechanisms. Neurology 1994;44:688-93.

40. Balla JI. The late whiplash syndrome. Aust NZ J Surg 1980;50:610-4.

41. Awerbuch MS. Whiplash in Australia: illness or injury? Med J Aust 1992;157:193-6.

42. Turk DC. The role of demographic and psychosocial factors in transition from acute to chronic pain. In: Jensen TS, Turner JA, Wiesenfeld-Hallin Z, eds. Proceedings of the 8th World Congress on Pain, Progress in Pain Research and Management, vol 8. Seattle: IASP Press, 1997:185-213.

43. Shapiro AP, Roth RS. The effect of litigation on recovery from whiplash. In: Teasell R, Shapiro A, eds. Spine: State of the Art Reviews. Cervical Flexion-Extension/Whiplash Injuries. Philadelphia: Hanley \& Belfus, 1993; 7:551-6.

44. Dworkin RH. Compensation in chronic pain patients: Cause or consequence? Pain 1990;43:387-8.

45. Swartzman LC, Teasell RW, Shapiro AP, McDermid AJ. The effect of litigation on adjustment to whiplash injury. Spine 1996;21:53-8.

46. Serlin RC, Mendoza TR, Nakamura Y. When is cancer pain mild, moderate or severe. Grading pain severity by its interference with function. Pain 1995;61:272-84.

47. Fishbain DA. Secondary gain concept. Definition problems and its abuse in medical practice. Am Pain Soc J 1994;3:264-73.

48. Berstad JR, Baerum B, Lochen EA, Mogstad TE, Sjaasta O. Whiplash: chronic organic brain syndrome without hydrocephalus ex vacuo. Acta Neurol Scand 1975;51:268-84.

49. Yarnell PR, Rossie GV. Minor whiplash head injury with major debilitation. Brain Inj 1988;2:255-8.

50. Olsnes BT. Neurobehavioural findings in whiplash patients with longstanding symptoms. Acta Neurol Scand 1989;584-7.

51. Kischka U, Ettlin TH, Heim S, Schmid G. Cerebral symptoms following whiplash injury. Eur Neurol 1991;31:136-40.

52. Radanov BP, Dvorak J, Valach L. Cognitive deficits in patients after soft tissue injury of the cervical spine. Spine 1992;17:127-31.

53. Levin HS, Eisenberg HM, Benton AL, eds. Mild Head Injury. New York: Oxford Press, 1989.

54. Gronwall D. Minor head injury. Neuropsychology 1991;5:253-66.

55. Kay T, Newman B, Cavallo M, et al. Towards a neuropsychological model of functional disability after mild traumatic brain injury. Neuropsychology 1992;6:371-84.

56. Ommaya AK, Fass F, Yarnell P. Whiplash injury and brain injury: An experimental study. JAMA 1968;204:285-9.

57. Wickstrom JK, Martinez JL, Rodriquez R, et al. Hyperextension and hyperflexion injuries to the head and neck of primates. In: Gurdijian ES, Thomas LM, eds. Neckache and Backache. Springfield: Chates C Thomas, 1970:108-17.

58. Domer FR, Lin YK, Chandran KB, Krieger KW. Effect of hyperextension-hyperflexion (whiplash) on the function of the blood brain barrier of rhesus monkeys. Exp Neurol 1979;63:304-10.

59. Liu K, Chandran KB, Heath RG, et al. Subcortical EEG changes in rhesus monkeys following experimental hyperextension-hyperflexion (whiplash). Spine 1984;9:329-38.

60. Shapiro AP, Teasell RW, Steenhuis R. Mild traumatic brain injury following whiplash. In: Teasell R, Shapiro A, eds. Spine: State of the Art Reviews. Cervical Flexion-Extension/Whiplash Injuries. Philadelphia: Hanley \& Belfus, 1993; 7:455-70.

61. Radanov BP, Dvorak J. Impaired cognitive functioning after whiplash injury of the cervical spine. Spine 1996;21:393-7.

62. Torres F, Shapiro SK. Electroencephalograms in whiplash injury. Arch Neurol 1961;5:28-35.

63. Gibbs FA. Objective evidence of brain disorder in cases of whiplash injury. Clin Electroencephalogr 1971;2:107-10.

64. Jacome DE. EEG in whiplash: A reappraisal. Clin Electroencephalogr 1987;18:41-5.

65. Crombez G, Eccleston C, Baeyens F, Eelen P. Habituation and the interference of pain with task performance. Pain 1997;70:149-54.

66. Gentilini M, Nichelli P, Schoenhuber R, et al. Neuropsychological evaluation of minor head injury. J Neurol Psychiatry 1985;48:137-40.

67. Huggenholtz H, Stuss DT, Stethem LL, Richard MT. How long does it take to recover from a mild concussion? J Neurosurg 1988;22:853-8.

68. Gronwall D. Cumulative and persisting effects of concussion on attention and cognition. In: Levin HS, Eisenberg HM, Benton AL, eds. Mild Head Injury. New York: Oxford University Press, 1989.

69. Ruff RM, Levin HS, Mattis S, et al. Recovery of memory after head injury. A three centre study. In: Levin HS, Eisenberg HM, Benton AL, eds. Mild Head Injury. New York: Oxford University Press, 1989:176-88

70. Weingartner H, Siberman E. Models of cognitive impairment: Cognitive changes in depression. Psychol Pharm Bull 1982;18:27-42.

71. Coyne JC, Gotlib IH. The role of cognition in depression: A critical appraisal. Psychol Bull 1983;39:593-7.

72. O'Hara MW, Hinrichs JV, Kohout FJ, et al. Memory complaint and memory performance in the depressed elderly. Psychol Aging 1986;1:208-14.

73. Jamison RN, Brocco TS, Parris WC. The influence of problems with concentration and memory on emotional distress and daily activities in chronic pain patients. Int J Psychiatry Med 1988;18:183-91.

74. Kewman DG, Vaishampayan N, Zald D, Han B. Cognitive impairment in musculoskeletal pain patients. Int J Psychiatry Med 1991;21:253-62.

75. Radanov BP, DiStefano GD, Schnidrig A, et al. Cognitive functioning after common whiplash. Arch Neurol 1993;50:87-91.

76. Ettlin TM, Kischka U, Reichman S, et al. Cerebral symptoms after whiplash injury of the neck: A prospective clinical and neuropsychological study of whiplash injury. Neurol Neurosurg Psychiatry 1992;55:943-8.

77. Provinciali L, Baroni M, Illuminati L, Ceravolo MG. Multi-modal treatment to prevent the late whiplash syndrome. Scand J Rehab Med 1996;28:105-11. 


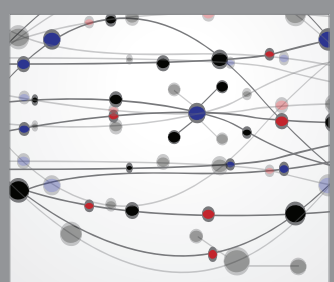

The Scientific World Journal
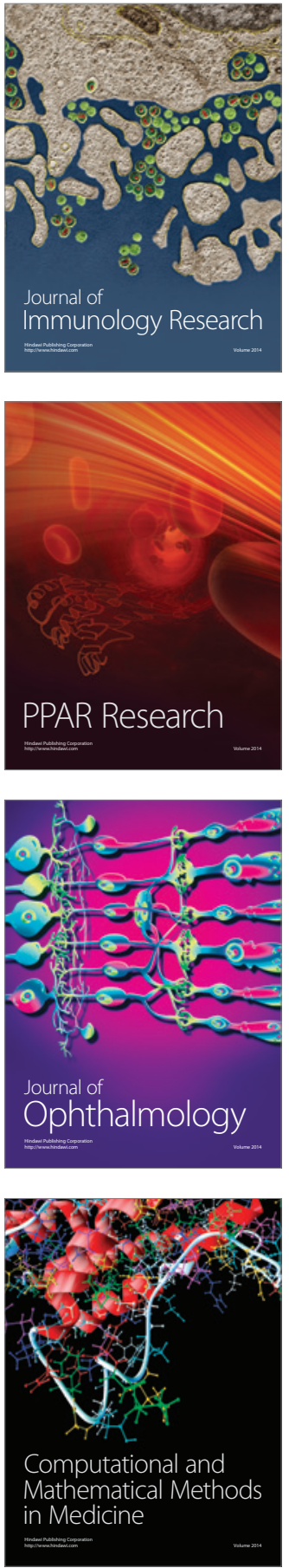

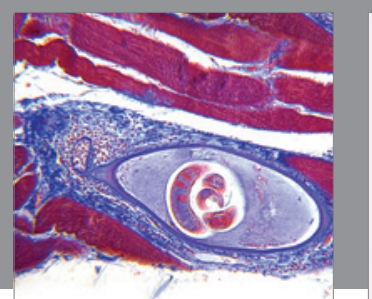

Gastroenterology Research and Practice

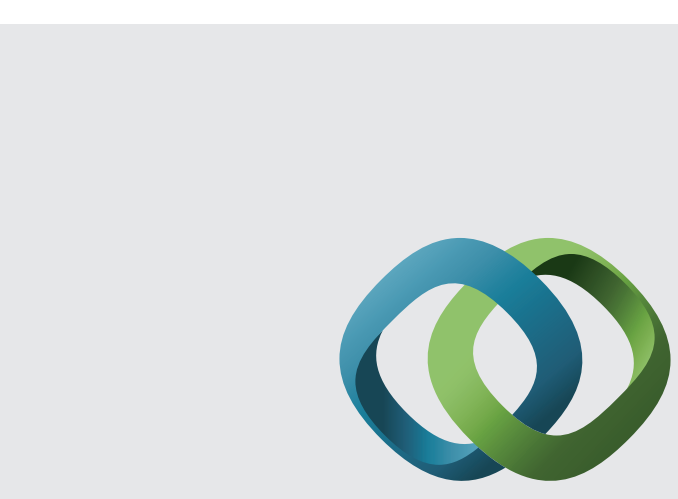

\section{Hindawi}

Submit your manuscripts at

http://www.hindawi.com
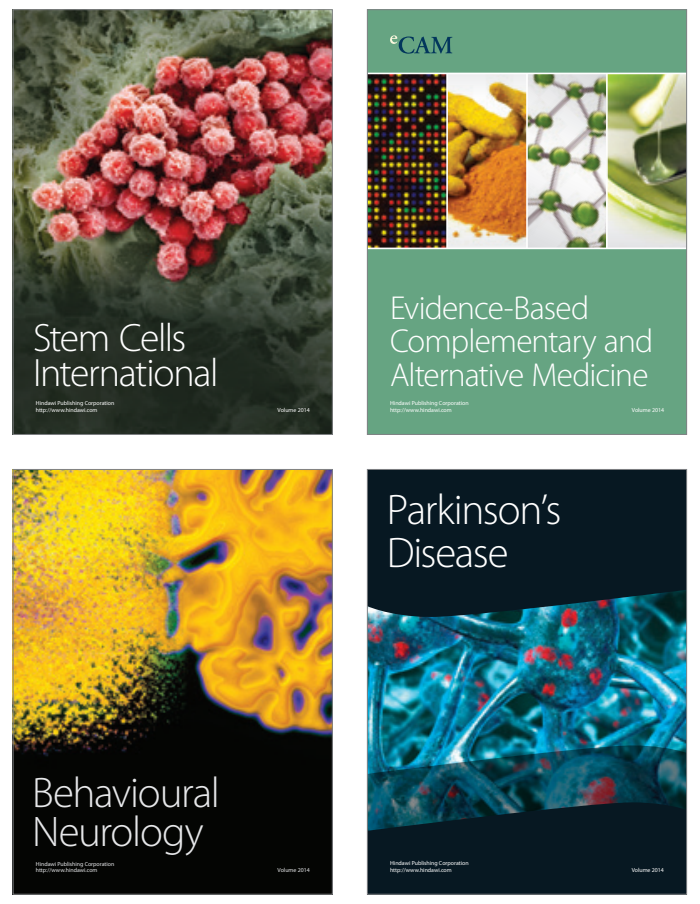
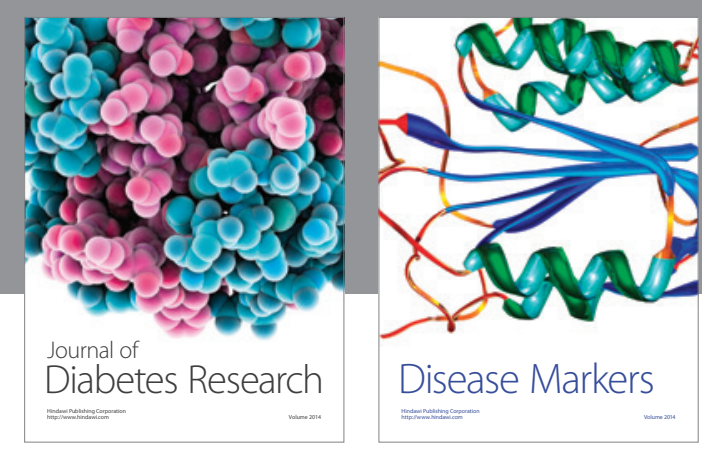

Disease Markers
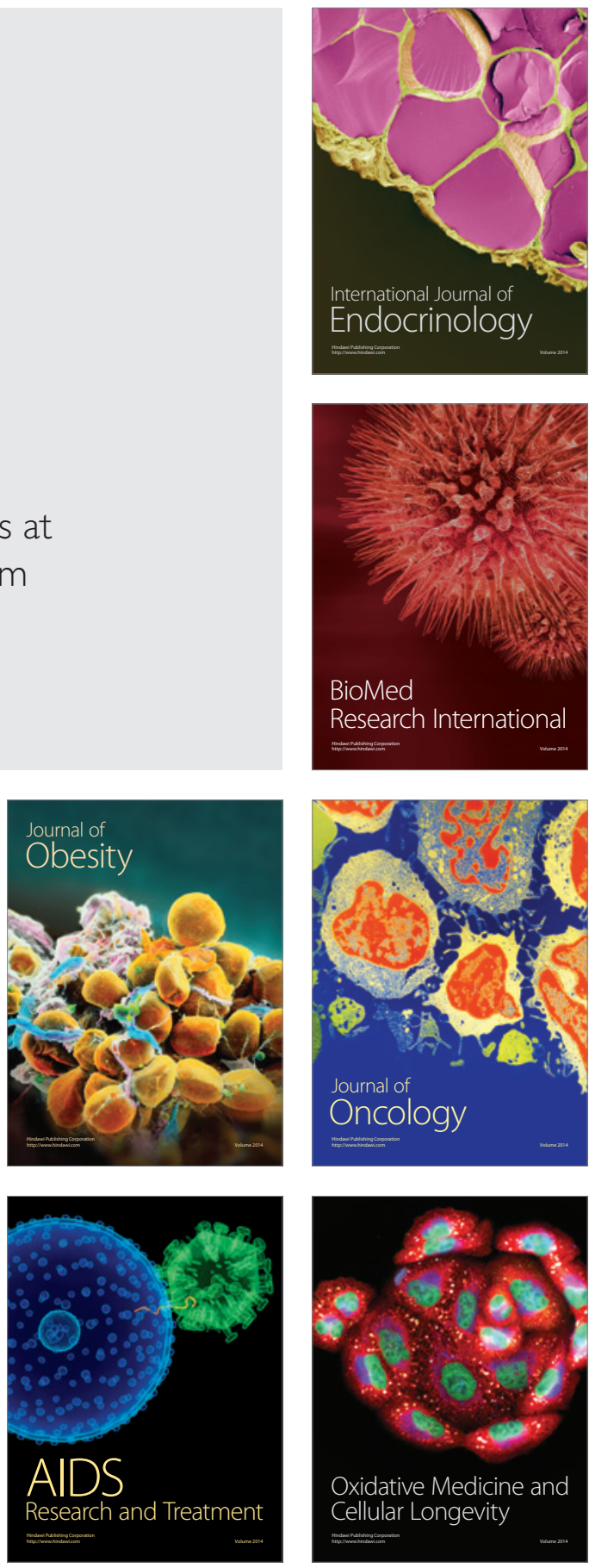